\title{
MULTI-BIOMARKER RESPONSES TO BIOACCUMULATION of DICLOFOP-METHYL in FRESHWATER FISH (Oreochromis niloticus).
}

\author{
Gamila, A. M. Kotb ${ }^{1}$; Sherif, H. Abd Al-Rahman ${ }^{2}$; Ahmed, A. Gh. Farag ${ }^{3}$ and \\ Manal E.A. Elhalwagy \\ 1- Mammalian and Aquatic Toxicology Dept., \\ 2- Pesticides Residues and Environmental Pollution Dept., \\ Central Agricultural Pesticide Laboratory, Agricultural Research Center, Giza, Egypt. \\ 3- Plant Protection Dept., Agriculture Faculty, Zagazig University, Egypt
}

\begin{abstract}
The present study was undertaken to assess the environmental hazards presented to wildlife by new pesticides or new uses of established pesticides, biochemical changes, residual behavior and accumulation of diclofop-methyl (Iloxan $36 \%$ EC) . A laboratory trials of diclofop-methyl were carried out on tilapia fish, Oreochromis niloticus as indicator species to . Acute toxicity of diclofop-methyl (Iloxan $36 \%$ EC) was carried out and the median lethal concentration for 96 hours (96 h - LC50) value was $1.89 \mathrm{mg} / \mathrm{l}$. In the present study, two groups of fish were exposed to two sub lethal concentrations selected on the basis of $1 / 10$ (0.19 mg / 1, low concentration) and $1 / 3$ (0.63 mg / 1, high concentration) of diclofop-methyl LC50 value for 28 days under the laboratory conditions compared to the control group. The treatments indicated that a gradual bioaccumulation of herbicide with time in whole fish was more pronounced than in muscle. Several criteria for estimating pesticide accumulation effect were studied on different biochemical parameters in plasma of fish after treatments. The results indicated that alanine aminotransferases (ALT), alkaline phosphatase (ALP) and acetylcholinesterase (AChE) activities as well as albumin and glucose levels increased significantly after treatment with both concentrations comparing to control group. However, significant increase in aspartate aminotransferases (AST) and total protein levels with was recorded low concentration $(0.19 \mathrm{mg} / \mathrm{l})$ only. On the other hand, high concentration $(0.63 \mathrm{mg} / \mathrm{l})$ caused significant increase in urea levels. However, ceriatinine level was decreased in both exposed concentrations. Noticeable changes in antioxidants biomarkers were recorded, a reduction in SH-protein level accompanied with an elevation in lipid peroxidation biomarker (MDA) were recorded in plasma after treatment with two concentrations. The previous results were accompanied with noticeable alterations in plasma and muscle protein patterns in both treated groups.
\end{abstract}

Key words: Diclofop-methyl, Herbicide, Bioaccumulation, Metabolic biomarkers, Fish, Oreochromis niloticus.

\section{Introduction}

Pesticides are used in agricultural treatments to reduce the negative impact of pests. Despite this benefit, the use of this kind of chemicals must be controlled because an important fraction of these pesticides are released into the environment presenting a potential hazard risk. Herbicides originating from agricultural activity enter the aquatic environment through atmospheric deposition, surface run-off or leaching and frequently accumulate in softbottom sediments and aquatic organisms (Miles and Pfeuffer, 1997; 
Lehotay et al., 1998; Kreuger et al., 1999). Persistence of herbicides in the aquatic environment depended on their properties and chemical structure. Some compound that have long time persistence accumulated in fish, causing toxic effect (Tilak et al., 2004). These herbicides are used as sodium or dimethylamino salts. Phenoxyherbicides are commonly used in agriculture such as diclofop-methyl, (methyl 2-[4-(2,4dichlorophenoxy) phenoxy] propanoate) is a selective post-emergence herbicide developed for use in control of wild oats, wild millets and other annual grass weeds in sunflowers, peanuts and dicotyledonous vegetable (Xu et al., 2008). Diclofop-methyl has been newly registered in Egypt as herbicide. The available data on behavior of this compound are very few, so there is need to study the behavior of this compound in the Egyptian environment. Among many properties available for describing distributions and environmental behavior of pesticides, the biological concentration factor (BCF) has proven very important as far as the behavior and fate of water-born chemicals in the aquatic environment is concerned (Taoshu et al., 2000). Aquatic organisms can accumulate chemicals present in the aquatic media. Some chemicals may be found only at low levels in various tissues, whereas others may build up to significant concentrations (Rand 1995). Fish are widely used to evaluate the health of aquatic ecosystems, and biochemical changes among fishe serve as biomarkers of environmental pollution (Schlenk and Digiulio, 2002). The tendency of the organism to bioaccumulate is measured by the bioconcentration factor (BCF) which is formally defined as the equilibrium ratio of the concentration of the substance in the exposed organism to the concentration of the dissolved substance bioavailable in the surrounding aquatic environment

(Mackay and Fraser, 2000). Fish with an average lipid content $(4.8 \%)$ are good model animals for bioconcentration studies (Barron, 1990). The objective of this study is assessment of $96 \mathrm{~h}-\mathrm{LC}_{50}$ value, determination of the uptake rate, bioconcentration factor $(\mathrm{BCFs})$ and to explain the biomarker responses that may be caused in tilapia fish exposed to diclofop-methyl with two concentration in aqueous solution for 28 days under the laboratory conditions.

\section{Materials and methods}

\section{1-Tested herbicide:}

Diclofop-methyl (Iloxan $36.0 \%$ EC) was used in this study. The formulation and active ingredient of diclofop-methyl were obtained from Bayer Ltd.

\section{2-Tested species:}

A total of 150 specimens of fish, Oreochromis niloticus (90 $\pm 10 \mathrm{~g}$ in weight) were obtained from Al-Abasa fish farm, randomly put in aerated glass aquarium $(100 \mathrm{~L})$ for each 10 fish and allowed to acclimatize under laboratory conditions for 14 days. The physico-chemical characters of water were measured according to (APHA 2005) and were maintained at optimum level, such as $\mathrm{pH}(7.1 \pm 0.2 \mathrm{mg} /$ $1)$, salinity (0), dissolved oxygen (8 - 8.6 mg / 1), total alkalinity ( $256 \pm 10.8 \mathrm{mg} / \mathrm{l})$, total hardness as $\mathrm{CaCO} 3(98.6 \pm 2.4 \mathrm{mg} / \mathrm{l})$, calcium $(68 \pm 6.5 \mathrm{mg} / \mathrm{l})$ and magnesium $(18 \pm 1.2 \mathrm{mg} / \mathrm{l})$. During the experiment, fish received an adequate human care under constant laboratory conditions (constant and continuous aeration, 12: $12 \mathrm{~h}$ light / dark cycle, $40-70 \%$ humidity at $27 \pm$ $2{ }^{\circ} \mathrm{C}$ ). The fish were fed daily with commercial pellets.

\section{3-Acute toxicity study:}

The $96 \mathrm{~h}-\mathrm{LC}_{50}$ value for diclofop-methyl were determined according to Organization 
for Economic Cooperation and Development Guidelines (OCED 1992) using sixty tilapia fish Oreochromis niloticus. The fish were exposed to six serial concentrations used concentrations of herbicide for 10 fish each concentration and numbers of died were counted up $96 \mathrm{~h}$ then the value of $\mathrm{LC}_{50}$ was calculated with Weil (1952).

\section{4-Bioaccumilation study:}

In the present study, bioaccumulation of diclofop-methyl in mcules of fish and the whole fish were monitored for the experimental period (28 days) under laboratory conditions. Freshly collected fish after acclimatization were divided into three groups of 30 fish in each group. Group 1 and 2 fish were exposed to diclofop-methyl with concentrations $1 / 10$ and $1 / 3 \mathrm{LC}_{50}$ as 0.19 and $0.63 \mathrm{mg} / 1$, respectively, and the remained group kept without treatment (unexposed group) as control. This study was patterned after the steady-state approach presented by (OECD 1996).

During experiment whole and muscle fish were taken after $0,7,14$ and 28 days of treatments for residual analysis to investigate the $\mathrm{BCF}$ while, blood samples were drawn from caudal vein with heparinized needles and syringes at the end of the experimental period ( 28 days). The blood samples were centrifuged at 5000 $\mathrm{rpm}$ for $10 \mathrm{~min}$. at $4{ }^{0} \mathrm{C}$. Plasma was collected and frozen at $-40{ }^{\circ} \mathrm{C}$ for assay of biomarker responses and protein electrophoresis.

Freezing muscles of fish were homogenized in Tris buffer $(1: 2 \mathrm{w} / \mathrm{v})$ containing $100 \mu \mathrm{l}$ of 2-mercaptoethanol $(\mathrm{pH} 7.5)$ at the end of the experimental period. The homogenate was centrifuge at $12000 \mathrm{~g}$ for $10 \mathrm{~min}$. at 4 ${ }^{0} \mathrm{C}$. The supernatant was stored at $-20{ }^{0} \mathrm{C}$ until electrophoresis of muscle protein.

\section{5- Residual analysis:}

\subsection{1-Sample preparation:}

Water samples $(500 \mathrm{ml})$ were collected from low and high concentrations at 1, 7, 14, 28 days during the exposure period. Water samples were extracted according the method described by (Madsen $\boldsymbol{e t}$ al., 2003). Fish samples were collected from two tested group during the exposure period. The samples were extracted using $10 \mathrm{~g}$ from homogenate fish samples in $50 \mathrm{ml}$ polypropylene centrifuge and add $20 \mathrm{ml}$ extraction mix contained acetonitrile $1 \%$ acetic acid, next centrifugation at rpm 4000 / 10 minutes. Then transform $5 \mathrm{ml}$ from supernatant to another clean $15 \mathrm{ml}$ polypropylene centrifuge tube and add $1 \mathrm{gm}$ $\mathrm{MgSO} 4$ anhydrous, 1gm sodium acetate dihydrate and $1 \mathrm{gm} \mathrm{NaCl}$ and then centrifugation at $5000 \mathrm{rpm} / 5$ minutes. Take $3 \mathrm{ml}$ from supernatant and evaporate the samples to $1 \mathrm{ml}$ for analysis.

\subsection{2-Calibration curve and assay validation:}

The series of diclofop-methyl standard solutions $(0.5,2.5,5,10,50,100$ and 200 $\mathrm{mg} / \mathrm{l})$ were prepared for linearity of the diclofop-methyl by diluted with acetonitrile the stock standard solution. Calibration curves were generated by plotting peak area versus concentration. Linear regression analysis was performed by using Microsoft Excel. The standard deviation (SD) and the relative standard deviation (RSD), RSD = $\mathrm{SD} /$ mean $\times 100$, were calculated at the entire calibration range. Recovery estimation was carried out over three concentration levels. The fish samples were prepared by adding the standard solutions in $10 \mathrm{~g}$ sample to get final concentrations of $0.20,2.0$ and $20.0 \mu \mathrm{g} / \mathrm{g}$. All the samples were extracted, purified and determined as previously described. The method recovery was estimated by comparing the ratio of the peak area after extracted from fish to those of an equivalent amount of the standard solution. The standard calibration offers excellent linearity with regression coefficient $r>0.998$, with good separation and good repeatability with limit of detection was $0.001 \mathrm{ppm}$, and relatively short retention time $(8.06 \mathrm{~min})$. The lowest possible standard on the calibration curve was accepted as the limit of quantification 
(LOQ). The calibration curve and recovery validation study were all repeated three times $(\mathrm{n}=3)$.

\subsection{3-Chromatographic Analysis:}

Samples were analysed by Agilent 7890 (USA) gas chromatography coupled with electron capture detector GC-ECD, using capillary column HP-5 (30 m $\times 0.25 \mathrm{~mm} \times$ $0.25 \mu \mathrm{m})$ and nitrogen gas was used as mobile phase at flow rate $2 \mathrm{ml} / \mathrm{min}$, with temperature program was started at $180^{\circ} \mathrm{C}$ hold on $1 \mathrm{~min}$ and increasing to 220 in rate in $25{ }^{\circ} \mathrm{C} / \mathrm{min}$, hold on 2 minute and increasing to reach $245{ }^{\circ} \mathrm{C}$ in rate $3{ }^{\circ} \mathrm{C} /$ min.

The mean recovery values from spiked samples with diclofop-methyl standard were ranged from $90-93 \%$ for water and $85-91 \%$ for fish samples.

\section{6-Biochemical Analysis:}

In plasma samples, the both of aspartate aminotransferases (AST) and alanine aminotransferases (ALT) activities were measured calorimetrically according to the method adopted by (Reitman and Frankel 1957). The activity of alkaline phosphatase (ALP) was measured by calorimetrically method of (Belfild and Goldberg 1971). Standard and quantitative assay for determination protein content in plasma and tissue fraction (homogenated muscles) done based the method of (Bradford 1976). Albumin content was measured by calorimetrically method of (Doumas et al. 1971). Plasma glucose concentration was determined by the method adopted by (Darham and Trinder 1972). Urea level was measured calorimetrically by the method of Fawcett and Soctt (1960).

Creatinine was determined by calorimetrically method of Schirmeister (1964). Plasma acetylcholinesterase (AChE) was assayed by the method of Ellman et al. (1961). Malondaldehyde (MDA) occurs in lipid peroxidation and was measured according to Ohkawa et al. (1979) in the plasma after incubation at 95 ${ }^{\circ} \mathrm{C}$ with thiobarbituric acid in aerobic conditions ( $\mathrm{pH}$ 3.4). The pink color produced by these reactions was measured spectrophotometrically at $532 \mathrm{~nm}$ to measure malondaldehyde levels.

Electrophoretic separation of proteins (plasma and muscles): SDS-PAGE electrophoresis was carried out according to the method of Laemmli (1970). The wide range of SDS-PAGE molecular weight prestained standers mix (Bio-Rad) was applied to the first well. Scanning was applied using Gel Prosoftware Version 3 for Media Sci. Image densitometry 700 Biorad, USA. A pool of 5 samples from plasma fish in each group has been used for the electrophoritic separation.

\section{7- Statistical Analysis Procedures:}

In evaluating the data obtained from the bioconcentration test, a steady-state approach was used. This consists of a two compartment model (water and fish) which was used to describe the movement of the test substance into and out of the test fish. This approach was used to determine the steady-state bioconcentration factor (BCF), the uptake rate constant $\left(\mathrm{K}_{1}\right)$, and the depuration rate constant $\left(\mathrm{K}_{2}\right)$. To exemplify this approach, the following reaction is presented:

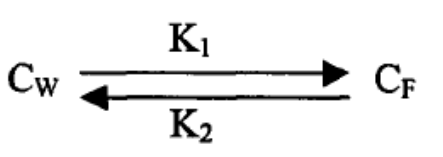

where:

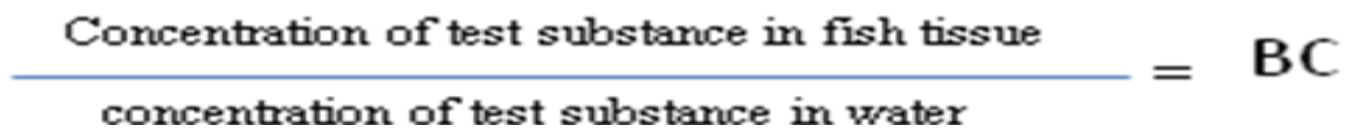

In additional, all data from biochemical analysis were subjected to statistical analysis by 
one-way Analysis of variance (ANOVA) test (Gad 1999\& 2001) using SPSS software for Windows version 17. A probability of $p \leq 0.05 ; \mathrm{p} \leq 0.01 ; \mathrm{p} \leq 0.001$ as the level of significance were considered unless stated otherwise.

\section{Results}

3.1- Determination of $96 \mathrm{~h}-\mathrm{LC}_{50}$ : The median lethal concentration for 96 hours $\left(96 \mathrm{~h}-\mathrm{LC}_{50}\right)$ value of diclofopmethyl to fish Oreochromis niloticus was $1.89 \mathrm{mg} / 1$.

\section{2- Bioaccumulation Results:}

The results presented in Table (1) showed the accumulation of diclofop-methyl residues in two fish groups exposed to 0.19 and $0.63 \mathrm{mg} / 1$, as one-tenth and one-third of $\mathrm{LC}_{50}$, respectively. It could be seen from the results that the bioaccumulation of diclofop-methyl was in order whole fish > muscle. Further, the accumulation in group 2 which exposed to one-third of $\mathrm{LC}_{50}$ was higher than group 1 which exposed to onetenth of $\mathrm{LC}_{50}$, indicating that the positive relation between pesticides concentration and BCF in fish. The highest level of accumulation for diclofop-methyl $(\mathrm{BCF}=$ 7.05and 9.21) was found in the whole fish for group1 and group2, respectively. However, the muscle recorded the low values $(\mathrm{BCF}=1.61$ and 2.15$)$ for group 1 and group 2 , respectively.

Table (1): Concentration ( $\mu \mathrm{g} / \mathrm{g}$ ) and Boconcentration of Dilofop-methyl in Mscle and whole Fish Oreochromis niloticus, for 28 days.

\begin{tabular}{|c|c|c|c|c|c|c|c|c|}
\hline \multirow{3}{*}{$\begin{array}{c}\text { Time } \\
\text { nerind } \\
\text { (days) }\end{array}$} & \multicolumn{4}{|c|}{ Group $1(0.19 \mathrm{mg} / \mathrm{l})$} & \multicolumn{4}{|c|}{ Group $2(0.63 \mathrm{mg} / \mathrm{l})$} \\
\hline & \multicolumn{2}{|l|}{ Muscle } & \multicolumn{2}{|c|}{ Whole fish } & \multicolumn{2}{|c|}{ Muscle } & \multicolumn{2}{|c|}{ Whole fish } \\
\hline & Conc. & BCF & Conc. & BCF & Conc. & BCF & Conc. & $\overline{B C F}$ \\
\hline 1 & $\begin{array}{c}0.006 \pm \\
0.01\end{array}$ & 0.02 & $\underset{0.02}{0.123} \pm$ & 0.63 & $\begin{array}{c}0.008 \pm \\
0.01\end{array}$ & 0.03 & $\begin{array}{c}0.36 \pm \\
0.04\end{array}$ & 1.78 \\
\hline 7 & $\begin{array}{c}0.09 \pm \\
0.05\end{array}$ & 0.42 & $\begin{array}{c}0.35 \pm \\
0.04\end{array}$ & 1.84 & $\begin{array}{c}0.16 \pm \\
0.03\end{array}$ & 0.79 & $\begin{array}{c}0.52 \pm \\
0.07\end{array}$ & 2.79 \\
\hline 14 & $\begin{array}{c}0.21 \pm \\
0.02\end{array}$ & 0.98 & $\begin{array}{c}0.98 \pm \\
0.09\end{array}$ & 5.11 & $\begin{array}{c}0.29 \pm \\
0.04\end{array}$ & 1.46 & $\begin{array}{c}1.26 \pm \\
0.11\end{array}$ & 6.42 \\
\hline 28 & $\begin{array}{c}0.34 \pm \\
0.04\end{array}$ & 1.61 & $\begin{array}{c}1.36 \pm \\
0.13\end{array}$ & 7.05 & $\begin{array}{c}0.43 \pm \\
0.08\end{array}$ & 2.15 & $\begin{array}{c}1.80 \pm \\
0.15\end{array}$ & 9.21 \\
\hline
\end{tabular}

\section{3- Biochemical Results:}

Data presented from Table (2) showed the marked changes in enzymes activities and biomarker levels. Significant increase in AST (at low concentration, $\mathrm{p} \leq 0.001$ ), ALT and alkaline phosphatase activates (in both experimental groups) were found compared to the controls. Significant increase of $\mathrm{T}$. protein in fish in the group exposed to low concentration $(\mathrm{p} \leq 0.05)$, meanwhile, there was an increase in glucose contents in both tested concentrations of diclofop was observed compared to the controls. In addition to these changes, higher albumin level was noticed in plasma fish in both exposed groups. Urea level in plasma was higher in fish treated with high concentration ( $\mathrm{p} \leq$ $0.001)$ as compared to the control. However, there is a significant reduction in creatinine level in both exposed concentrations compared with control group was shown in Table (2), these changes were more in high concentration than in low concentration. The demonstrated data in Table (3) reported that, the stimulation of $\mathrm{AChE}$ activity $(\mathrm{P} \leq$ 
0.001) in both exposed groups of fish Oreochromis niloticus compared to control $(137 \%$ at low and $134 \%$ at high concentration) was recoded. On the other hand, there is a reduction in total $\mathrm{SH}$ Proteins levels $(\mathrm{P} \leq 0.001)$ in both exposed groups to diclofop-methyl. This reduction was correlated with significant increase in MDA biomarker of lipid peroxidation. Regarding to the plasma protein pattern, Table (4) and Fig. (3) Depicted the alterations in protein bands in plasma. Total numbers of bands in both treated groups were smaller than in control group. There are five bands disappear (band 94, 86, 18,11and $10 \mathrm{KD}$ ), while two bands (band 30 and $16 \mathrm{KD}$ ) are new in both treated groups compared with control. On the other hand, total number of protein muscles bands in low group was more than in control and high concentration groups because there are four consequence bands (band 16, 14, 13 and $12 \mathrm{KD}$ ) were appeared with low concentration treatment only. Also, there are two bands appear (band 11 and $8 \mathrm{KD}$ ) or disappear (43 and $39 \mathrm{KD}$ ) in both treated groups as shown in Table (4) and Fig. (4). According to all electrophoretic data of protein plasma and muscle, we can conclude that:

1- In the two exposed groups, the total numbers of protein muscles bands were increased while were decreased in plasma comparing with the control group.

2- The band that its molecular weight 11 $\mathrm{KD}$ was disappeared in electrophoretic pattern of plasma protein pattern while in muscle protein pattern it was appeared.

3 - The band that its molecular weight 10 $\mathrm{KD}$ was disappeared in electrophoretic of plasma protein pattern while in muscle protein pattern it was increased in exposed groups.

4- The amount of band $5 \mathrm{KD}$ was increased in width in both plasma and muscle protein pattern according to the concentration of the tested herbicide compared to control group.

5- The total numbers of bands which disappeared in plasma protein pattern $(5$ bands) were higher than in the muscle protein pattern ( 2 bands).

Table (2): Changes in some Plasma Biomarkers Of Liver and Kidney Functions of Fish Oreochromis niloticus Exposed to Diclofop-methyl for 28 days.

\begin{tabular}{|c|c|c|c|}
\hline Parameters & Control & $\begin{array}{c}\text { Group 1 } \\
(0.19 \mathrm{mg} / \mathrm{l})\end{array}$ & $\begin{array}{c}\text { Group } 2 \\
(0.63 \mathrm{mg} / \mathrm{l})\end{array}$ \\
\hline \multicolumn{3}{|c|}{ Liver Function } & \\
\hline$\overline{A S T}(\mathbf{U} / \mathbf{L})$ & $35.13 \pm 2.37$ & $76.178 \pm 6.38 * * *$ & $46.11 \pm 3.96$ \\
\hline ALT (U / L) & $24.81 \pm 1.56$ & $33.35 \pm 2.34^{*}$ & $36.26 \pm 2.42 * *$ \\
\hline $\operatorname{ALP}(\mathbf{U} / \mathbf{L})$ & $10.52 \pm 1.03$ & $17.27 \pm 1.39 * *$ & $14.72 \pm 1.01 *$ \\
\hline T. Protein (g / dl) & $3.33 \pm 0.14$ & $3.91 \pm 0.08 *$ & $3.69 \pm 0.17$ \\
\hline Albumin (g / dl) & $0.50 \pm 0.04$ & $2.32 \pm 0.21 * * *$ & $1.18 \pm 0.12 * *$ \\
\hline Glucose (mg / dl) & $133.91 \pm 11.32$ & $189.64 \pm 16.57 *$ & $220.8 \pm 15.40 * *$ \\
\hline \multicolumn{4}{|c|}{ Kidney Function } \\
\hline Urea (g / dl) & $0.25 \pm 0.019$ & $0.252 \pm 0.02$ & $0.46 \pm 0.015 * * *$ \\
\hline $\begin{array}{l}\text { Creatinine } \\
(\mathrm{mg} / \mathrm{dl})\end{array}$ & $0.93 \pm 0.03$ & $0.67 \pm 0.006 * *$ & $0.77 \pm 0.07 *$ \\
\hline
\end{tabular}


Values represent means \pm SEM (five fish).

* significant differences versus control at $\mathbf{p} \leq \mathbf{0 . 0 5}$.

$* *$ significant differences versus control at $\mathbf{p} \leq$

0.01.

$* * *$ significant differences versus control at $\mathbf{p} \leq$

Table (3): Changes in Plasma Acetylcholinesterase (AChE) and Antioxidant Biomarkers (T. SH-Protein and MDA) of Fish Oreochromis niloticus Exposed to Diclofop-methyl for 28 days.

\begin{tabular}{|l|c|c|c|}
\hline Parameters & Control & $\begin{array}{c}\text { Group 1 } \\
(0.19 \mathrm{mg} / \mathrm{l})\end{array}$ & $\begin{array}{c}\text { Group 2 } \\
(0.63 \mathrm{mg} / \mathrm{l})\end{array}$ \\
\hline $\begin{array}{l}\text { AChE activity } \\
(\mu \mathrm{mol} / \mathrm{min} / \mathrm{ml})\end{array}$ & $115.70 \pm 5.05$ & $158.80 \pm 1.42 * * *$ & $155.28 \pm 5.24 * * *$ \\
\hline$\%$ Activity & & $137 \%$ & $134 \%$ \\
\hline $\begin{array}{l}\text { T. SH-Protein } \\
(\mathrm{mmol} / \mathrm{l})\end{array}$ & $444.71 \pm 38.68$ & $193.60 \pm 9.33^{* * *}$ & $160.88 \pm 14.66 * * *$ \\
\hline $\begin{array}{l}\text { MDA } \\
(\mathrm{nmol} / \mathrm{l})\end{array}$ & $8.62 \pm 0.09$ & $13.47 \pm 0.35 * * *$ & $23.57 \pm 0.37 * * *$ \\
\hline
\end{tabular}

Values represent means \pm SEM (five fish).

* significant differences versus control at $\mathrm{p} \leq \mathbf{0 . 0 5}$.

$* *$ significant differences versus control at $\mathbf{p} \leq \mathbf{0 . 0 1}$.

$* * *$ significant differences versus control at $\mathbf{p} \leq \mathbf{0 . 0 0 1}$. 
Table (4): Changes in Plasma and Muscle Electrophoretic Protein Pattern of Fish Oreochromis niloticus Exposed to Diclofop-methyl for 28 days.

\begin{tabular}{|c|c|c|c|}
\hline \multicolumn{4}{|c|}{ Plasma } \\
\hline Conc. & Control & Low & High \\
\hline $\begin{array}{l}\text { M.W } \\
(\mathbf{K D})\end{array}$ & & & \\
\hline $94 * *$ & 6.97 & & \\
\hline 88 & & 10.3 & \\
\hline $86 * *$ & 5.07 & & \\
\hline 84 & & & 11.4 \\
\hline 70 & 7.12 & & 22.2 \\
\hline 56 & 3.46 & 13.2 & \\
\hline 43 & 9.87 & 2.04 & \\
\hline $30 *$ & & 4.88 & 11.4 \\
\hline 24 & & 4.25 & \\
\hline $18 * *$ & 4.43 & & \\
\hline $16 *$ & & 0.257 & 2.06 \\
\hline 15\#\# & 1.469 & 2.03 & 1.96 \\
\hline 14\# & 4.16 & 0.788 & 1.03 \\
\hline 13 & 4.16 & 2.99 & \\
\hline $11 * *$ & 0.738 & & \\
\hline $10 * *$ & 0.331 & & \\
\hline 9 & 0.31 & 0.063 & \\
\hline 8 & 7.35 & 5.21 & \\
\hline 7 & 10.6 & 6.18 & \\
\hline 6 & 2.95 & 4.15 & \\
\hline 5\#\# & 17.4 & 19.0 & 20.5 \\
\hline $\begin{array}{l}\text { Total } \\
\text { number } \\
\text { of } \\
\text { bands }\end{array}$ & 16 & 14 & 7 \\
\hline
\end{tabular}

*Appear. ** Disappear. decreased.

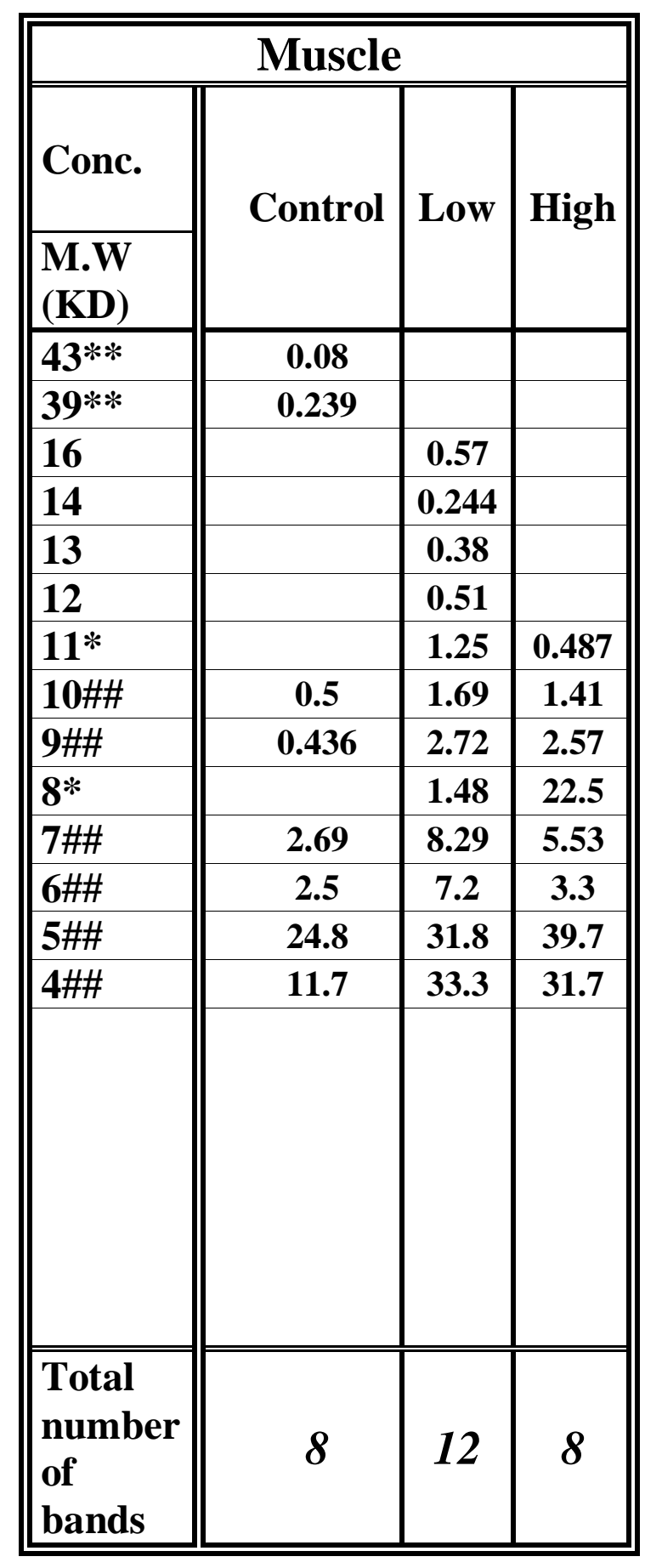

\#\# Amount increased.

\# Amount 


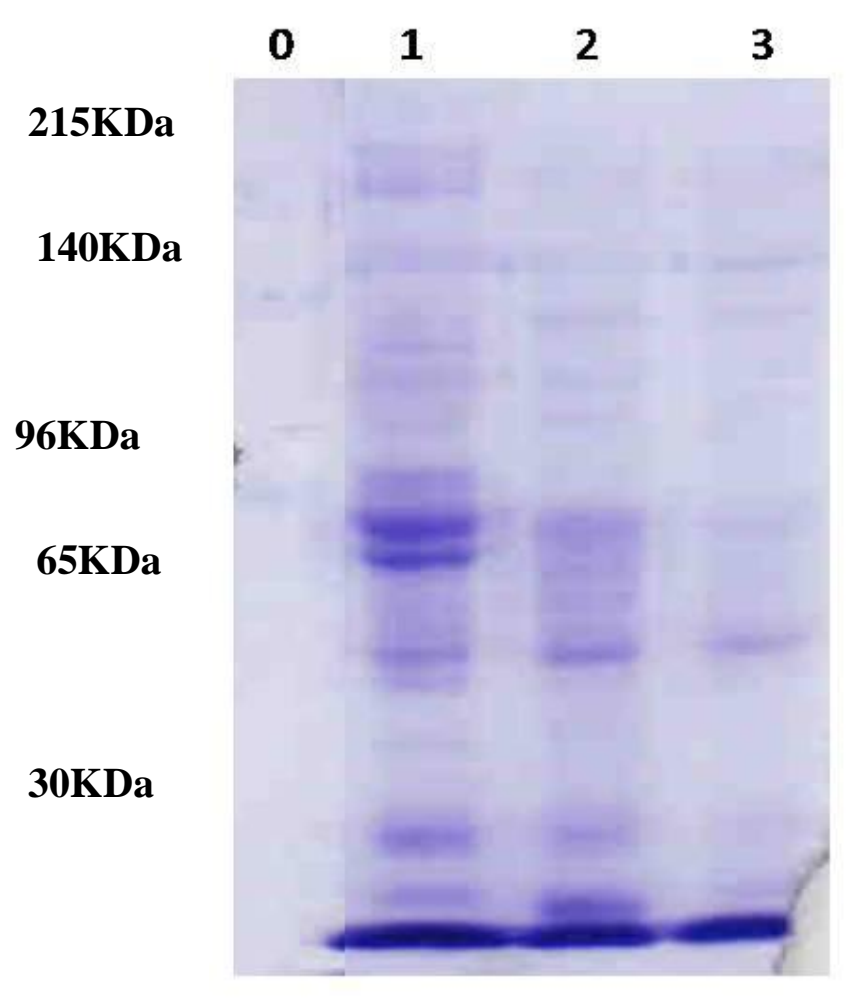

Fig. (1): Effect of diclofop-methyl on plasma protein pattern of fish Oreochromis niloticus for 28 days.

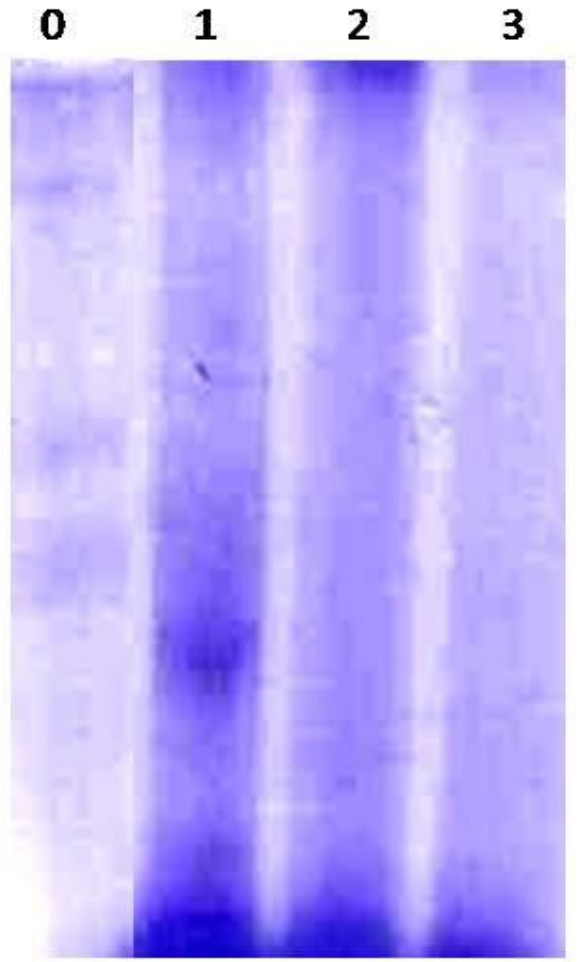

Fig. (2): Effect of diclofop-methyl on protein pattern in muscles of fish Oreochromis niloticus for 28 days.

Lane $0=$ Protein Marker.

Lanes 1= High concentration for 28 days respectively.

Lanes $2=$ low Conc. after 28 days respectively.

Lanes 3 = Control for 28 days respectively.

\section{Discussion}

Herbicides are one of the main groups of chemicals that could impair aquatic ecosystems (Dorigo et al., 2003). Fish have the potential to bioaccumulation contaminants ingested with food and bioconcentrate chemicals from water via diffusion across the gills and skin (Maule $\boldsymbol{e t}$ al. ,2007). Bioaccumulation in fish is influenced by factors specific to the chemical component, the environmental conditions, the exposure route and the species. Models must capture the combined effects of these factors in bioaccumulation through a set of parameters. These interactions are best understood for the case of organic contaminants, where the bioaccumulation factor has been found to be correlated in most cases to their octanolwater partition coefficient $\left(\mathrm{K}_{\mathrm{OW}}\right)$. Whereas in mechanistic models this factor affects the absorption and elimination rate constants of the substance (Veltman et al., 2008). Since the interaction between contaminants and biomolecules is the first step in the generation of toxic effects, understanding biochemical alterations induced by the exposure to pollutants may contribute to the prediction of toxic effects that may occur later at higher levels of biological organizations. In this direction, some antioxidant enzymes have been proposed as biological indicators of pollutant exposure in aquatic organisms (Winston and Giulio, 1991). Fish blood cells have relatively high antioxidant defense levels including enzymatic and non-enzymatic systems 
(Roche and Boge, 1996). During the last twenty years, a large body of biomonitoring data has been accumulated in order to assess whether lower level responses could be used as indicators to determine toxic effect of xenobiotics (Triebskorn et al., 2001).

Recently more attention has been given to tissue-specific contaminant distribution (Monosson et al., 2003; Sapozhnikova et al., 2005). The accumulation of diclofopmethyl in fish muscle was low in concentration might be due to the low amount of lipids in fish muscle (Ferrando et al., 1991; Larsson et al., 1991). Alanine (ALT) and aspartate (AST) transaminases activities may be used as sensitive markers in experimental pesticide intoxication in teleost fish (Beyer et al., 1996). There is an elevation of liver enzymes activities in the plasma, this increase may be due to tissue damage, particularly in the liver, or due to alterations in the permeability of cell membrane and increased synthesis or decreased catabolism of aminotransferases (Begum, 2004). These results are in agreement with those reported by Begum and Vijayaraghavan (1996) who observed that, AST and ALT were increased in fish, Clarias batrachus, which exposed to dimethoate. The high levels of protein are synthesized by liver, which needed for repair of damaged cell organelle and tissue regeneration. Furthermore, a compensatory production of enzymes lost as a result of tissue necrosis or to meet increased demand to detoxify the pollutants might necessitate to enhanced synthesis of enzyme proteins (Gill et al., 1990). One of the characteristics of pesticides is induction of stress that is a response to every situations which threatening homeostasis and result in activation of hypothalamic pituitary adrenal (APA) axis and sympathetic autonomic nervous system, which consequently lead to hyperglycemia. This stimulation of sympathetic nervous system during stress leads to enhanced release of catecholamine, glucagon and growth hormone which result in promotion of gluconeogenesis, glycogenolysis, insulin resistance and constitution of hyperglycemia (Mechanick, 2006), these facts explain significant elevation in plasma glucose as a result of herbicide intoxication which recorded in the present study. An impairment of kidney functions was recorded in the present study. These effects could also be attributed to the changes in the threshold of tubular reabsorption, renal blood flow and glomerular filtration rate (Zurovsky and Haber, 1995). The reduction in creatinine level could be attributed to the significant loss of muscle mass in treated fish (Lees et al., 1994). The stimulation of AChE activity in both exposed groups of fish may be explained by that tested substance (diclofop-methyl) may couple with of $\mathrm{AChE},{ }^{\mathrm{s}}$ active substrate (Acetylcholine) or with its receptor. Glutathione is the major low-molecular-weight, non-enzymatic antioxidant; it quenches oxyradical through its -SH group (Zhang et al., 2004). Glutathione depletion is considered a biomarker of environmental stress as observed in fish stressed by environmental pollutants (Pena-Liopis et al., 2001; Venkateswara- Rao, 2006). Malondaldehyde content (MDA) is a major oxidation product of peroxidized polyunsaturated fatty acids and increased MDA content is an important indicator of lipid peroxidation (Freeman and Crolo, 1981). In the present study total SH-Proteins was depleted in all treatments, an indication of sever oxidative stress, and may lead to lipid peroxidation and tissue damage. Also, an increase in malondaldehyde (MDA), the biomarker of LPO, could be generation of free radicals by the alteration in the normal homeostasis of the body resulting in oxidative stress. The study also showed the resultant induction of antioxidant could not quench the generated ROS induced by the toxicant (Saez et al., 1990). Banding patterns of proteins down by the electrophoresis techniques are the wide spread methods helped to formulate a better idea about the physiological and genetic effects and the action of chemicals such as pesticide (Rizkalla et al., 1997).

The changes detected in muscles protein bands of Oreochromis niloticus after exposure to diclofop-methyl might be a result of the pesticide stress, and some unexpressed genes might have come to be 
expressed to contradict such effect (Rashed et. al., 1992).

Generally, from our results we are conclude that effect of low concentration on AST, ALP and AChE activities and albumin and total protein levels were more than the effect of high concentration. In contrast, influence of ALT activity and glucose, urea and MDA contents were highly with high concentration compared with low concentration. Additionally, influence of muscle protein pattern was hard with low concentration. These results were explained by (Palaniappan and Karthikeyan, 2009) who recommended that one of the most important properties of a toxic pollutant is its ability to accumulate in the tissues of organisms. Over a long period, the pollutants present in the environment at very low levels may accumulate within the body of aquatic species by various mechanisms to the extent that they exert References

American Public Health Association (APHA, 2005): Standard methods for the examination of water \& wastewater.136 ${ }^{\text {th }}$ Annual Meeting, San Diego.

Barron M G (1990): "Bioconcentration." Environ. Sci. Technol. 24: 1612 - 1618.

Begum G (2004): Carbofuran insecticide induced biochemical alteration in liver and muscle tissues of the fish Clarias batrachus and recovery response. Aquatic Toxicol., 66: 83 92.

Begum G and Vijayaraghavan S (1996): Alterations in protein metabolism of muscle tissue in the fish (Clarias batrachus) by commercial grad dimethoate. Bull. Environ. Contam. Toxicol., 57: 223 - 238.

Belfild A and Goldberg D M (1971): determination of alkalin phosphatase. Enzyme, 12: 561.

Beyer J, Sondvik M, Hyll K, Fjeld E, Eguas E, Aas E, Skare J U and Goksayr A (1996): Contaminant accumulation and biomarker responses in flounder and Atlantic cod exposed by caging to polluted sediments in sorfjorden, Norway. Aquat. Toxicol., 36: 75 - 98.

Bradford M M (1976): A rapid and sensitive method for the quantitation of microgram quantities of protein utilizing the principle of protein-dye binding." Anal Biochem., 72: 248254. toxic effects. Therefore, it is of great importance to know the bioaccumulation potential of a pollutant.

Finally, because of diclofop-methyl is a newly registered in Egypt as herbicide, there are few studies have clearly accounted for the cause and effect regarding suspected diclofop-methyl herbicide contamination and bioaccumulation of the aquatic environment. So in future research, we need to consider of this compound in the Egyptian environment, not only direct effects of single parent diclofop-methyl, but also indirect effects caused by its mixtures with other pesticides, including possible pesticide transformation products and numerous other biomarker responses have been widely used in field bio-monitoring studies as well as in laboratory investigations.

Darham B and Trinder P (1972): An improved color reagent for determination of blood glucose by the oxidase system. Analyst., 97: 142 - 145.

Dorigo U, Bourrain X, Berard $A$ and Leboulanger $\mathbf{C}$ (2003): Seasonal changes in river microalgae sensitivity to atrazine and isoproturon, along a contamination gradient. Sci. Total Environ., 318: $101-114$.

Doumas B T, Watson W A and Biggs H G (1971): Quantitative colorimetric determination of albumin in serum or plasma. Clin. Chem. Acta, 31: 87 - 91.

Ellman G L, Couriney K D, Andres V J and Featherstone R M (1961): A new and rapid colorimetric determination of acetyl cholinesterase activity. Biochem. Pharmacol., 7: 88 - 95.

Fawcett J $\quad$ K and Soctt J $\quad$ E (1960): Determination of urea (urease modified Berthelot reaction). J. Clin. Path., 13: 156 159.

Ferrando M D, Sancho $E$ and AndreuMoliner E (1991): Comparative acute toxicities of selected pesticides to Anguilla anguilla. J. Environ Sci Health B 26(5-6): 491 $-498$.

Freeman B A and Crolo J D (1981): Hyperoxia increases oxygen radical production in rat lungs and lung mitochondria. J. Biol. Chem., 256: 10986 - 10992.

Gad S C (1999): Statistics and experiment design for toxicologist. $\mathbf{3}^{\text {rd }} \boldsymbol{E d}$., Edit by $\boldsymbol{C R C}$ Press, LLC, New York, USA: 175 - 200. 
Gad S C (2001): Statistics for toxicologist. In: "Principles and methods of toxicology". Edit by Hayes, W. A. $4^{\text {th }}$ Ed., Taylor \& Francis, USA: $285-364$.

Gill T S, Pande J and Tewari H (1990): Sublethal effects of an organophosphorus insecticide on certain metabolite levels in a freshwater fish, puntius conchonius. Pest. Biochem. Physiol., 36: 290 - 299.

Kreuger J, Peterson $M$ and Lundgren $E$ (1999): Agricultural inputs of pesticide residues to stream and pond sediments in a small catchment in southern Sweden. Bul. of Environ. Contam. Toxicol., 62: 55 - 62.

Laemmli U K (1970): Cleavage of structural proteins during the assembly of the head of bacteriophage T4. Nature, 227: 680 - 685.

Larsson P, Hamrin S and Okla L (1991): Factors determining the uptake of persistent pollutants in an eel population (Anguila anguilla L.). Environ Pollut 69(1): 39-50.

Lees G E, Willard M D and Grean R A (1994): Urinary disorders. In "Small Animals Clinical Diagnosis by Laboratory Methods", edit by Willard, M. D.; Tavedten $H$ and Tummwald G H Eds, W B Sunders Co. : 141 $-145$.

Lehotay S J, Harman-Fetcho J A and McConnell L L (1998): Agricultural pesticide residues in oysters and water from two Cheaspeake Bay tributaries. Marine Pollution Bulletin, 37: 32 - 44.

Mackay D and Fraser A (2000): Kenneth Mellanby Review Award. Bioaccumulation of persistent organic chemicals: mechanisms and models. Environ Pollut., 110(3): 375 - 91.

Madsen T J, Leak T and Meyer B N (2003): Bioconcentration and Metabolism of [dichlorophenyl-U-MC]-diclofop-methyl in Bluegill, Lepomis. Bayer CropScience Study No. 601BL.

Maule A G, Gannam A $\mathbf{L}$ and Davis $\mathbf{J}$ W (2007): Chemical contaminants in fish feeds used in federal salmonid hatcheries in the USA. Chemosphere 67(7): 1308 - 1315.

Mechanick J I (2006): Metabolic mechanisms of stress hyperglycemia. J. Parenter. Enteral. Nutr., 30: 157- 163.

Miles CJ and Pfeuffer R J (1997): Pesticides in canals of South Florida. Arch. Environ. Contam. Toxicol., 32: 337 - 345.

Monosson E, Ashley J T, McElroy A E, Woltering D and Elskus A A (2003): PCB congener distributions in muscle, liver and gonad of Fundulus heteroclitus from the lower Hudson River Estuary and Newark Bay. Chemosphere 52(4): 777 - 787.
OECD, Organization for Economic Cooperation and Development, (1992): Guideline for the testing of chemicals: Fish Acute Toxicity Test, No 203.

OECD (1996): Bioconcentration: Flow Through Fish Test. TG305, 1996.

Ohkawa H, Ohishi N and Yagi K (1979): Assay for lipid peroxides in animal tissues by thiobarbituric acid reaction. Anal. Biochem., 95: 351 - 358 .

Palaniappan PL and Karthikeyan S (2009): Bioaccumulation and depuration of chromium in the selected organs and whole body tissues of freshwater fish Cirrhinus mrigala individually and in binary solutions with nickel. J. Environ. Sci., 21: 229 - 236.

Pena-Liopis S, Pena J B Sancho E, Fernandez-Vega $C$ and Ferrando $M \quad D$ (2001): Glutathione-dependent resistance of the European eel Anguilla anguilla to the herbicide molinate. Chemosphere 45: 671 - 681 .

Rand G M (1995): Fundamentals of Aquatic Toxicology. second ed., Taylor \& Francis, Florida.

Rashed M A, Ibrahim S A, El-Saeoudy A A, Abd-El-Tawab F M, and Ahmed G E (1992): Effect of pollutant with organophosphorus insecticide (Tamaron) in muscle protein electrophoresis to some tilapia species. Egypt. J. Appl. Sci., 7: 497 - 510.

Reitman $S$ and Frankel S (1957): A colorimetric method for the determination of serum glutamic oxalacetic and glutamic pyruvic transaminases. Am J. Clin. Pathol., 28(1): 56 63.

Rizkalla E H, Gamal A A, Mahmoud A A, Shawky A S and Ramadan A A (1997): Effects of some pesticides on the sarcoplasmic protein fractionation of common carp, Cyprinus carpio. Egypt. J. Agric. Res., 75: 225 - 245.

Roche $H$ and Boge $G$ (1996): Fish blood parameters as a potential tool for identification of stress caused by environmental factors or chemical intoxication. Mar Environ. Res., 41: 27 - 44.

Saez GT, Bannister W H and Bannister J V (1990): Free radicals and thiol compounds: The role of glutathione against free radical toxicity. In "Glutathione Metabolism and Physiological Functions'. Vina, J. (Ed.), CRC Press, Boca Raton, FL,: 237 - 254.

Sapozhnikova Y, Zubcov N, Hungerford S, Roy $L$ A, Boicenco N, Zubcov $E$ and Schlenk D (2005): Evaluation of pesticides and metals in fish of the Dniester River, Moldova. Chemosphere 60(2): 196 - 205. 
Schirmeister J (1964): determination of creatinine level. Dtsch. Med. Wschr. 89: 1940 - 1947.

Schlenk D and Digiulio $R \quad$ (2002): Biochemical responses as indicators of aquatic ecosystem health. In "Biological indicators of aquatic ecosystem stress". Adams SM, editor. Bethesda, Maryland: American Fisheries Society 57: 13 - 42 .

Tao Shu H, Hu X, Lu R W and Dawson F (2000): Fragment constant method for prediction of fish bioconcentration factors of non-polar chemicals. Chemosphere 41(10): $1563-1568$.

Tilak K S, Veeraiah K and Rao D K (2004): Toxicity and bioaccumulation of chlorpyrifos in Indian carp, catla catla. Bull. Environ. Contam. Toxicol. 73: 933 - 941.

Triebskorn R, Böhmer J, Braunbeck T, Honnen W, Köhler H-R and Lehmann R (2001): The project VALIMAR (VALIdation of bioMARkers for the assessment of small stream pollution): objectives, experimental design, summary of results, and recommendations for the application of biomarkers in risk assessment. J. Aquat Ecosyst Stress Recovery, 8: $161-78$. Veltman K, Huijbregts M A J, Van Kolck $M$, Wang $W X$ and Hendriks A $J$ (2008): Metal bioaccumulation in aquatic species: quantification of uptake and elimination rate constants using physicochemical properties of metals and physiological characteristics of species. Environ. Sci. Technol., 42 (3): 852 858.

Venkateswara-Rao J (2006): Biochemical alterations in euryhaline fish, Oreochromis mossambicus exposed to sub-lethal concentrations of an organophosphorus insecticide, monocrotophos. Chemosphere 65: $1814-1820$.

Weil C S (1952): Tables for convenient calculation of median effective dose (LD50 and ED50) and instruction in their use. Biometrics, 8: $249-263$

Winston G Wand Giulio R T (1991): Prooxidant and antioxidant mechanisms in aquatic organisms. Aquat. Toxicol., 19: 137 161.

Xu G, Peng W, Donghui L, Yuele $L$ and Zhiqiang $\mathbf{Z}$ (2008): Stereoselective degradation of diclofop-methyl in soil and Chinese cabbage. Pesticide Biochem. Physiol., 92: 1 - 7 .

Zhang J F, Shen H, Wang X R, Wu J C and Xue Y Q (2004): Effects of chronic exposure of 2,4-dichlorophenol on the antioxidant system in liver of freshwater goldfish Carassius auratus. Chemosphere, 55: 167 - 174.

Zurovsky $Y$ and Haber $C$ (1995): Antioxidants attenuate endotoxin-generation induced acute renal failure in rats. Scand $\boldsymbol{J}$. Urol Nephrol., 29: 147 - 154. 


\title{
المؤثرات الحيوية العديدة للتراكم الحيوى لمبيد الداكلوفوب-ميثيل فى سمك المياة العذبة (البلطى النيلى Oreochromis niloticus).
}

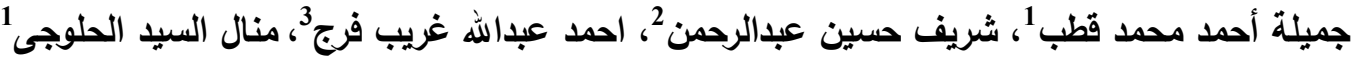

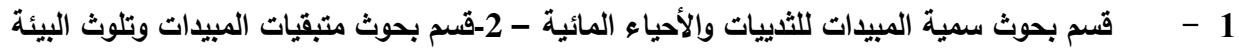 \\ المعمل المركزى للمبيدات - مركز البحوث الزراعية - الاقى - جيزة - مصر . \\ 3- قسم وقاية النبات - كلية الزراعة - جامعة الزقازيق - مصر.
}

لكى يتم تقييم الأخطار البيئية لمبيدات جديدة او لمبيدات قديمة ثم يوصى باستخدامها لمكافحة الآفات على نباتات أخرى. فلابد من دراسة تأثثرها على الحباة البرية لذا نقوم باجراء دراسات لتقدير تاثثر تللك المركبات على المعايير

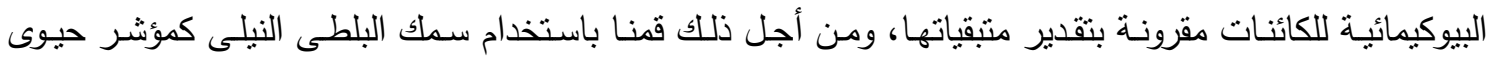

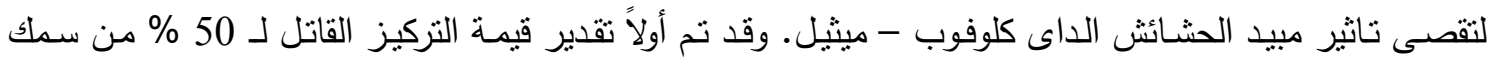
البلطى لمدة 96 ساعة ( 96 hr - LC 96 ) وقد كان 1.89 مجم / لتر ـ ثم تم معاملة السمك بتركيزين من المبيد

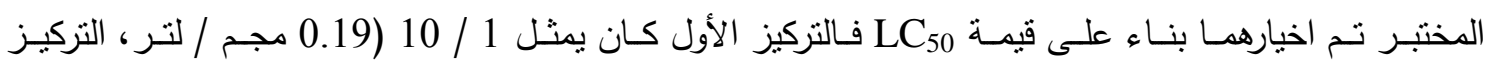

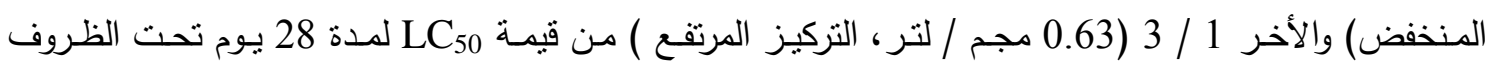

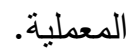

وأوضحت المعاملات أن التأثثرات الفسيولوجية للمبيد فى السمك يمكن توضيحها بكلاً من التأثيرات البيوكيميائية

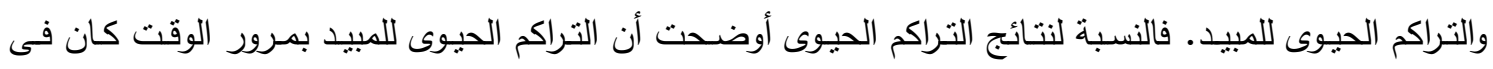

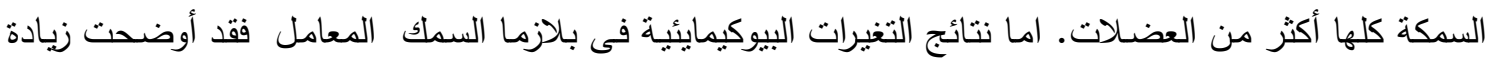
معنويـة فحى نشاط كلا من أنزيم ALT و ALP و AChE بعد التعرض لكلا التركيزين مقارنة بالأسماك غير

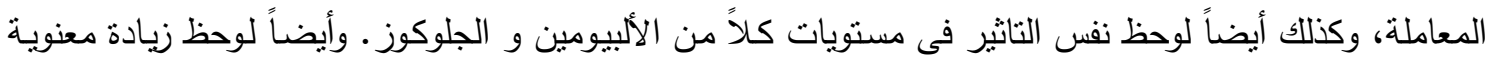
فى نشاط انزيم AST ومستوى البروتينات الكلية مع التركيز المنخفض فقط ( 0.19 مجم / لتر ). ومن ناحية أخرى

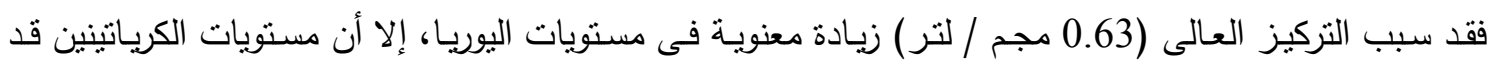

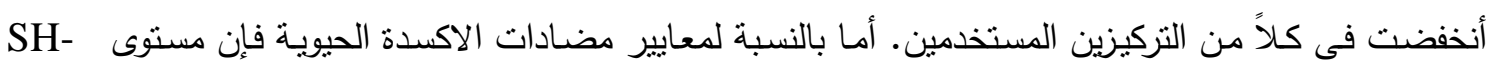
Protien المعرضة لتركيزى المعاملة. وأيضاً لوحظت تغيرات فى صورة برونينات البلازما والعضـلات عند تفريدهما كهربائيًا فى الأسماك المعرضة للتركيزين المستخدمين. 